\title{
Temporal changes in caiçara artisanal fishing and alternatives for management: a case study on the southeastern Brazilian coast
}

\author{
Priscila Fabiana Macedo Lopes ${ }^{1,3}$ \& Alpina Begossi ${ }^{2}$ \\ ${ }^{1}$ Pós Graduação em Ecologia, Instituto de Biologia, Universidade Estadual de Campinas - UNICAMP, \\ Rua Monteiro Lobato, 255, CEP 13083-970, Campinas, SP, Brazil, \\ http://www.ib.unicamp.br/ensino/pos/cursos/pos_ecologia/index.html \\ ${ }^{2}$ Programa de Capacitação de Pescadores Artesanais para o Manejo da Pesca, \\ Pró Reitoria de Extensão e Assuntos Comunitários - PREAC, \\ Universidade Estadual de Campinas - UNICAMP, \\ Rua da Reitoria Prédio da Reitora I, CEP 13083-970 Campinas, SP, Brazil \\ ${ }^{3}$ Corresponding author:Priscila Fabiana Macedo Lopes, e-mail: pmaccord@gmail.com, \\ http://www.fisheriesandfood.org/ing/fifo.htm
}

\begin{abstract}
MACCORD, P.F.L. \& BEGOSSI, A. 2008. Temporal changes in caiçara artisanal fishing and alternatives for management: a case study on the southeastern Brazilian coast. Biota Neotrop. 8(2): http://www.biotaneotropica. org.br/v8n2/en/abstract?article+bn00708022008.
\end{abstract}

Abstract: This paper describes a case study of the changes in fishing that occurred in a Brazilian coastal community after a 10 year interval (1992-2002). There was a decrease in the mean amount of fish caught daily (from $14 \mathrm{~kg}$ to $11.32 \mathrm{~kg}$ ) and annually (from $4.2 \mathrm{t}$ to $3.4 \mathrm{t}$ ) and in the richness of species caught (from 21 to 17 species); there was also a low similarity in the species composition of the fish landings (Morisita-Horn index $\mathrm{Ch}=0.24$ ). These changes suggested a decline in the locally exploited fish populations, which probably caused the discontinuation of commercial artisanal fishing. However, the diversity of fish caught by hook and line and purse-seine fishing was higher in the second period, whereas there was no significant difference in the diversity of fish caught using gillnets. Despite these changes, the CPUE showed no significant alteration and non-intensive fishing is still practiced by a few (6-35) people in the community. Co-management alternatives (fishing regulations, oysterfarms, ecotourism, etc.) are suggested and may be applicable to other coastal communities after appropriate adaptation for each location.

Keywords: fishery, Atlantic coast community, co-management, temporal changes.

MACCORD, P.F.L. \& BEGOSSI, A. 2008. Mudanças temporais na pesca artesanal caiçara e alternativas para manejo: um estudo de casa na costa sudeste do Brasil. Biota Neotrop. 8(2): http://www.biotaneotropica. org.br/v8n2/pt/abstract?article+bn00708022008.

Resumo: O uso de recursos por comunidades humanas tem influência direta na conservação da biodiversidade, na medida em que a forma como ele é executada pode implicar em conservação ou sobre-uso dos recursos. Este artigo descreve um estudo de caso sobre as mudanças ocorridas na pesca em uma comunidade da costa brasileira ao longo de 10 anos (1992-2002). Houve um decréscimo das quantidades médias capturadas diariamente (de $14 \mathrm{~kg}$ para $11.32 \mathrm{~kg}$ ) e anualmente (de $4.2 \mathrm{t}$ para $3.4 \mathrm{t}$ ) e também na riqueza de espécies (de 21 para 17 espécies). Além disso, a similaridade da composição de espécies presentes nos desembarques pesqueiros entre os dois períodos foi baixa. (Índice de Morisita-Horn $\mathrm{Ch}=0.24$ ). Estas mudanças sugerem um declínio das populações de peixes exploradas localmente, o que provavelmente causou o fim da pesca artesanal comercial. No entanto, a diversidade de espécies capturadas com caniço e com o cerco com redes foi maior no segundo período, enquanto não houve diferença significativa na diversidade de peixes capturada com redes de espera. Apesar destas mudanças, não houve alteração significativa na CPUE e a pesca não intensiva é ainda praticada por alguns membros da comunidade (6-35). Algumas medidas de co-manejo, baseadas no que já é de certa forma realizado pela comunidade (controle da pesca, cultivo de ostras, ecoturismo, etc.), são propostas e podem ser aplicadas a outras comunidades costeiras após serem apropriadamente adaptadas às características locais, objetivando a manutenção do uso continuado dos recursos, mas de forma racional.

Palavras-chave: pesca, comunidades da costa brasileira, co-manejo, mudanças temporais. 


\section{Introduction}

In recent decades, there has been increased interest in the exploitation of fishing stocks and in features linked to the behavior of fishermen, such as their use of time and space when fishing (Begossi 1996, Cetra \& Petrere 2001, Guest 2003). This interest has resulted partly from failure in the management of fisheries, which has been attributed to the lack of information on the features of each local fishery and on the fisherman involved (Hilborn 1985, Jentoft \& McCay 1995). Current studies try to assess not only the stocks of fish available, with emphasis on ecological studies of commercially important species, but also consider the actual catches (Friedlander \& Parrish 1997) in order to provide a more coherent idea about the situation. Factors such as poverty and unplanned habitat occupation by humans increase the vulnerability of fishing exploitation, a situation aggravated by the usually open-access situation of maritime resources (Feeny et al. 1990).

Although small-scale fishing is often associated with non-intensive estuarine, coastal or reef fishing, it can contribute to the decline of important species, particularly when dynamite or cyanide fishing is used (Jiddawi \& Öhman 2002). Even the use of simple techniques, such as hook and line, have reduced the fishing stocks in some places, thereby changing the structure of local fishing and invertebrate communities (de Boer et al. 2001, Ruttenberg 2001). In response to such problems, some fishing communities have developed management strategies, including the self-regulation of extraction activities (Berkes 1985), restoring the legal acceptance of old management techniques (Levieil \& Orlove 1990, McGrath et al. 1993, McDaniel 1997). In other cases, however, management is still very informal (Reis \& D'Incao 2000, Begossi \& Brown 2003).

The implementation of management alternatives must be based on solid knowledge of the local systems of resource exploitation (Berkes, 1985) since the traditional mode of exploitation used by a given community can result in unintentional conservation of resources (Aswani 1998). The evaluation of such systems depends on the study of fishermen's behavior and this involves a deep understanding of their fishing strategies and decisions concerning where and when to fish (Seixas \& Begossi 2000).

In Brazil, studies of artisanal fishing have dealt with a variety of environments, such as rivers (Cetra \& Petrere 2001, Silvano \& Begossi 2001), lakes (MacCord et al. 2007), reefs (Costa et al. 2003) and coastal areas (Hanazaki \& Begossi 2000, Begossi 2004). However, fewer studies have addressed temporal changes in artisanal fisheries (Okada et al. 2005), mainly due to the scarcity of data since there is no systematic recording of fish landings in the vast majority of Brazilian fishing communities.

Many of the coastal studies in Brazil have been done in the state of São Paulo. Despite being the most industrialized state in the country, São Paulo still has some small-scale artisanal communities that maintain old traditions in daily life, especially concerning resource use. However, these communities are facing important changes. On the one hand, they have access to facilities that improve their welfare (bus services, electricity, etc.) while on the other hand, they encounter difficulties in using resources because of restrictions imposed by governmental agencies. The inhabitants of these coastal communities, the caiçaras, are descendants of Indians and Portuguese, and originally survived on fishing and cassava slash-and-burn agriculture. Some of these fishing communities still exploit a high diversity of fish for commercialization, consumption and popular medicine (Begossi 1996, Hanazaki \& Begossi 2000).

In this work, we sought to understand the temporal changes in small-scale fishing communities based on an analysis of the variation in diversity, composition and amount of fish caught over a 10 year period (1992/3 to 2002/3) in a caiçara community at Puruba Beach on the São Paulo coast. We also analyzed the main changes in fishing strategies throughout this period. Finally, we examined the main factors that caused such variations and their implications for the conservation of local resources. Based on these findings, we have proposed alternatives for the management of natural resources. We hope that the findings of this study may lead to the adoption of more effective, locally relevant management strategies in caiçara and other small-scale fishing communities.

\section{Material and Methods}

\section{Study site}

The Puruba Beach community ( $23^{\circ} 21^{\prime} \mathrm{S}$ and $44^{\circ} 55^{\prime} \mathrm{W}$, Ubatuba city, São Paulo state) is located in a coastal area of Atlantic forest (Figure 1a), one of the most threatened biomes in Brazil (Myers et al. 2000). This community is on the border of a state park (Parque Estadual da Serra do Mar), a region of conflict between local dwellers (caiçaras) and IBAMA, the Brazilian Environmental Protection Agency. The conservation strategy officially adopted for this region does not take into account the people who have lived in the Atlantic forest for centuries, and imposes restrictions on the use of resources without first consulting with the local community to help them find alternatives to meet their needs. This has led to the exodus of many people to coastal towns, and has increased the already existing slums in urban regions. The community is bordered by two rivers (Puruba and Quiririm), which attract sport fishermen to the estuary. Besides, the place is surrounded by wonderful mountains, with some trails used mainly by local people, as tourists usually do not go beyond the beach.

Only 22 families live in the community at Puruba, since caiçara communities tend to be small. The cultivation of swiddens was abandoned because of governmental restrictions that forbid the slash-andburn method inherited from Indians. Many dwellers sold these plots to tourists, who built houses to rent to other tourists during holidays, a contradictory situation that is not subject to environmental restrictions and is difficult to prevent. Some of the common consequences of tourism, such as hotels and restaurants on the beach, are not seen at Puruba because commercial activities on the beach are subject to environmental restrictions. However, some dwellers have improvised small restaurants in their houses, which open during the holidays. Despite the peculiarities common to each caiçara community, this general pattern is seen on almost every beach where such communities occur (Diegues 1999). Many inhabitants of Puruba now work outside the community since fishing is becoming more and more difficult and there are few alternatives of employment. Despite these limitations, few people move to other places, mainly because land is passed down to sons and daughters. Some former tourists, who now reside on the place, in collaboration with local people, were trying to establish an oyster farm in the estuary by the time of this study. However, they were stuck in the difficult part of convincing some of the local people to work in a cooperative way, since these ones would prefer to develop the place and establish their own restaurants on the beach. Some people invest in tourism as a secondary activity, for example, changing their yards in camping sites during the high season and holidays. The houses rented for seasonal tourists usually belong to the former tourists, so that part of the money generated by tourism does not come back to the local community. Nonetheless, these new houses are usually built by local people who make a living off of working in constructions and are then maintained by local women who work as maids. So even though tourism is now part of their daily lives under different aspects, it is not clear yet the real 

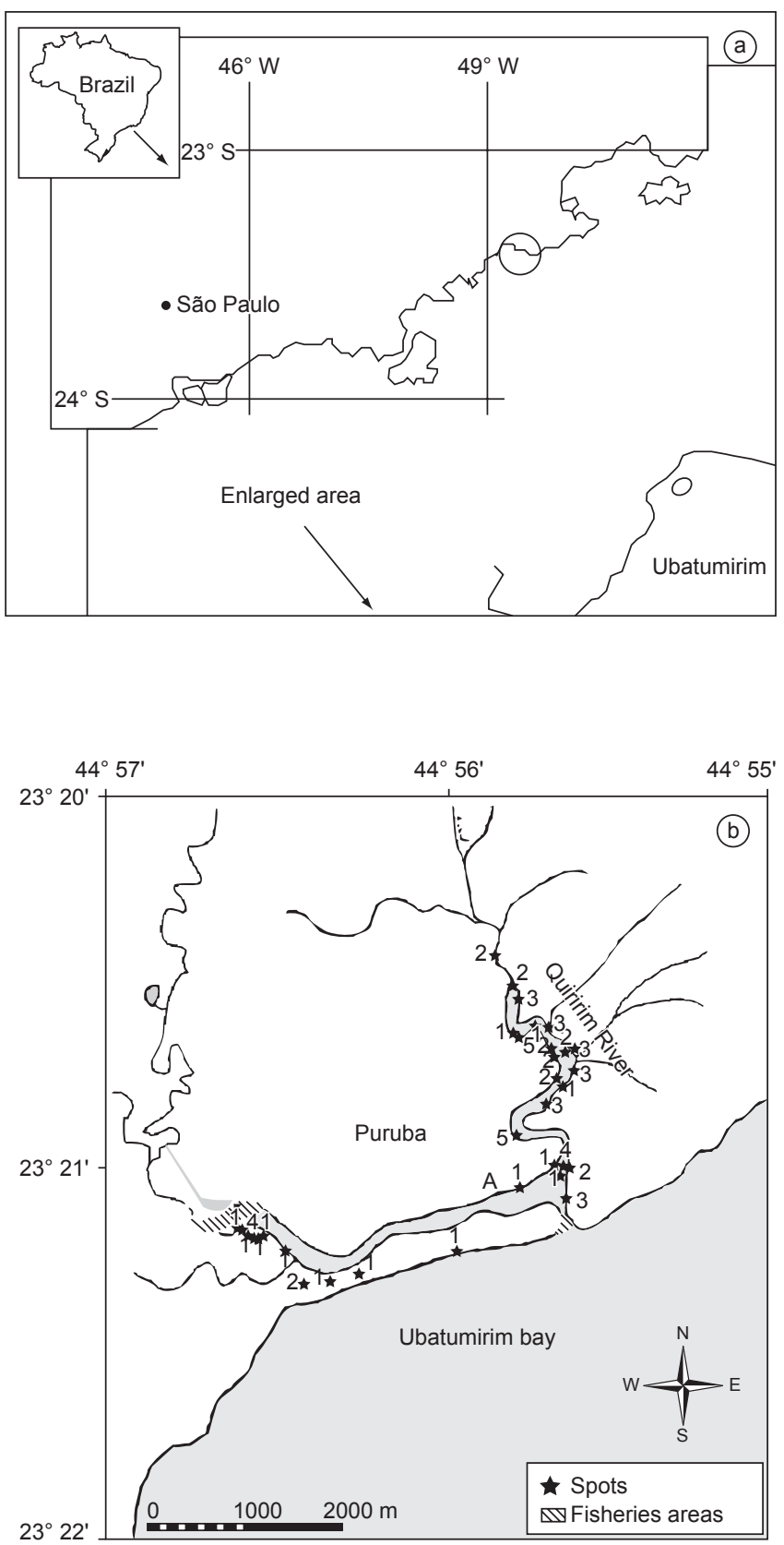

Figure 1. a) Map of Puruba Beach; and b) Fishing spots used by Puruba fishermen based on the two periods described in the text (adapted from Begossi 2004).

Figura 1. a) Mapa da Praia do Puruba; e b) Locais de pesca utilizados pelos pescadores baseados nos dois períodos descritos no texto (adaptado de Begossi 2004).

benefits it brings to the village, as most of it translates into temporary or underpaid jobs.

\section{Data collection}

Fish landings were sampled for 10 days each month for six months in 2002 and 2003. These data were collected at the main fish landing points and at the fishermen's houses. The fish were weighed separately when possible, and were usually sorted by folk species, according to the fishermen's nomenclature, or classified as a mixture when there were many small individuals of different species together. We interviewed the fishermen about the name of and distance to (in time - minutes) the fishing grounds, the duration of fishing activity and the technology used. Some fish specimens were collected for later identification. The fishing grounds were subsequently marked using a GPS.

Since this same methodology was used in a study 1992/93 (Begossi 1995), it was possible to compare the same six corresponding months sampled 10 years apart.

\section{Data analysis}

Fish weighed data is derived from fish weighed by the researcher and unweighed fish (because of their very large size), their weight being estimated by the fishermen. In the statistical comparisons, both values were used since the fishermen were very accurate in their estimates (Spearman's correlation for the weight estimated by fishermen versus the weight obtained using a weighing scale: $r_{s}=0.99$; $\mathrm{p}<0.0001 ; \mathrm{n}=30$ ).

The Morisita-Horn Simplified Similarity Coefficient, which estimates abundance based on biomass, was used to assess the similarity in the composition of fish landings in both periods. The Shannon-Wiener diversity index was used to compare the fish caught by each fishing technology. The richness used in the diversity index may not have been exact since in some cases the fish were weighed as a mixture in which there were some very small fish that were difficult to identify or because the same popular name was applied to different species. A $t$ test was used to compare differences between the diversity indexes in the two periods (Magurran 1988).

The CPUE was calculated as the weight of fish caught $(\mathrm{kg}) \times$ the number of fishermen ${ }^{-1} x$ the total fishing time in minutes ${ }^{-1}$ (including travel time to fishing grounds). The average values of CPUE obtained for each period were compared using the $t$ test and tested by randomization using the bootstrap method (1000 simulations). We used a Chi-square test to compare the frequency that each fishing method was used between the periods.

\section{Results}

\section{Fishing spots and fish-landing composition}

All fishing occurred very close to the community, indicating that the fishermen depended almost exclusively on the estuary and on the beach shore; this was confirmed by mapping all of the fishing spots in the two study periods (Figure 1b).

The 1992/93 sample recorded 108 fish landings during 58 days, with the participation of 21 fishermen. However, in terms of biomass, six fishermen were responsible for $88 \%$ of the fish landings. During 2002/03, 167 fish landings were recorded during 55 days and involved 35 fishermen. Again, only six fishermen accounted for most ( 60\%) of the biomass caught during the fishing trips (only one fisherman was common to both periods). The fishermen visited 25 fishing spots in 1992/93 and 21 in 2002/03. Each fishing trip yielded an average of $7.56 \mathrm{~kg}$ in $1992 / 93$ and $3.76 \mathrm{~kg}$ of fish in 2002/03, with $21.3 \%$ and $25 \%$ of the sampled trips resulting in no yields in the first and second periods, respectively. Since one of the authors remained in the community all day and since the catches of rare night fishing expeditions were landed early in the morning, the daily average weight of fish captured (considering all the fishing trips) was $11.32 \mathrm{~kg}$ in 2002/03 and $14 \mathrm{~kg}$ in 1992/1993 (based on the same assumptions as used in 2002/03). Assuming 300 fishing days per year in this community, since they seldom fish on Sundays and holidays, the total weight of fish caught in 1992/93 was $\sim 4.2 \mathrm{t}$ per year and $~ 3.4 \mathrm{t}$ in 2002/03. 
The fishermen captured at least 21 species of fish in 1991/93 and 17 species in 2002/03. Centropomus spp. (Centropomidae), Mugil curema (Mugilidae) and Genidens genidens (Ariidae) accounted for $92 \%$ of the weight of fish landed in 1992/93. In 2002/03, Centropomus spp. Mugil curema, M. platanus and Lutjanus griseus (Lutjanidae) accounted for this same percentage. Although the same fish species were present in both periods, the fish landings in the two periods showed a low similarity $\left(\mathrm{C}_{\mathrm{H}}=0.24\right)$, mainly because the guri sea catfish (Genidens genidens) was substituted by the grey snapper (Lutjanus griseus), mullet (Mugil platanus) and snook (Centropomus spp.) in 2002/03 (Table 1).

Table 2 shows the low similarity between the periods in relation to the catch size, species richness and CPUE. In 1992/93, the catch was higher in January, and this resulted in a higher CPUE. However, the low diversity index suggested that the catch of almost $500 \mathrm{~kg}$ of guri sea catfish accounted for this difference. In 2002/03, October was the most productive month, but was not associated with the highest CPUE since the fishermen spent more time fishing, thereby increasing their fishing effort. This most recent period showed a low diversity index for all months, which suggested that the community was focusing on a smaller number of species (lower evenness in four months) (Table 2).

\section{Fishing technologies}

Four fishing methods were used in this community in both periods: hook and line, gillnet, purse-seine and beach seine fishing. Hook and line fishing was used in all habitats, with natural or artificial bait. Gillnet fishing implies in the use of one or more nets in rivers, placed early in the evening (after 6:00 PM) and removed early the next morning. The purse-seine method was also used in rivers to enclose a previously identified shoal of fish. In beach seine fishing, one of the sides of a large-meshed net is pulled by a boat containing up to four men, while the other side of the net remains on the beach, held by the other fishermen (up to 14 people). This method, although used in 1992/93, was not sampled. Since the use of this technique depends on favorable environmental conditions (the sea must be extremely calm), there are few days during the year that allow its use at Puruba Beach and these appropriate days did not coincide with our sampling periods. Although common to both periods, the frequency of use of each method was different $\left(\chi^{2}=21.27 ; p<0.0001\right)$, with purse-seine fishing being used four times more frequently in 1992/93 than in 2002/03, while gill net fishing was three times more common in 2002/03 than in 1992/93.

Fishing using beach seine was only done using big meshes and was aimed exclusively at larger fishes, such as grey snapper (L. griseus) and snook (especially C. undecimalis). Gillnets captured mainly mullet (Mugil platanus) in both periods, although white mullet (Mugil curema) now accounts for a significant proportion of the fish caught using this method. Purse-seine fishing has changed since it is no longer aimed at capturing guri sea catfish (Genidens genidens). In both periods, hook and line fishing yielded the highest diversity of species since the same bait can be used to catch many different fish species (Figure 2). The changes that have occurred in the fishing procedures are reflected in the diversity of species caught with each technique. Hook and line and purse-seine fishing yielded the greatest variety of species in the second period, whereas there was no significant difference in the diversity of species caught using gillnets (Table 3).

The CPUE did not change significantly in the two periods (bootstrap: $\mathrm{p}>0.05$ ), although there was a tendency for the CPUE to decrease since four of the six months considered showed lower median values in the most recent period (Table 2).

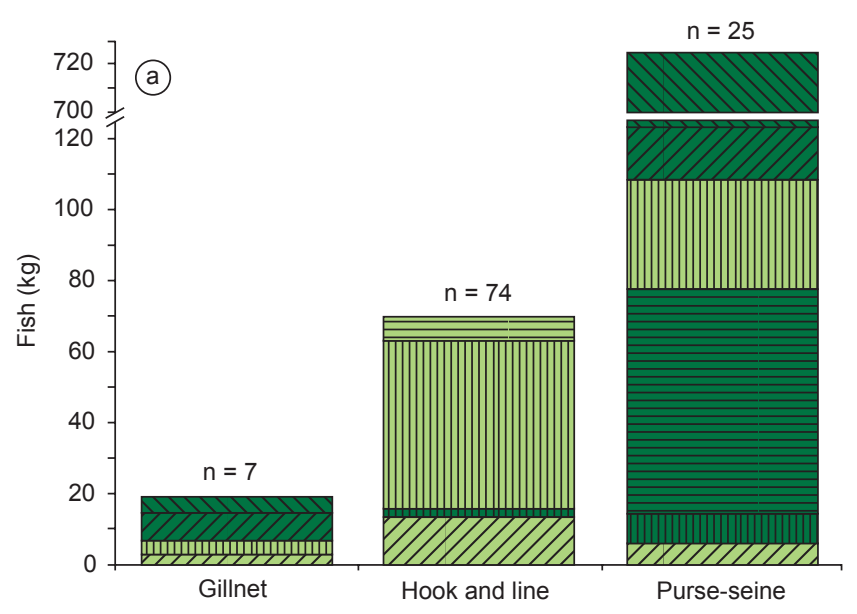

Fishing technology
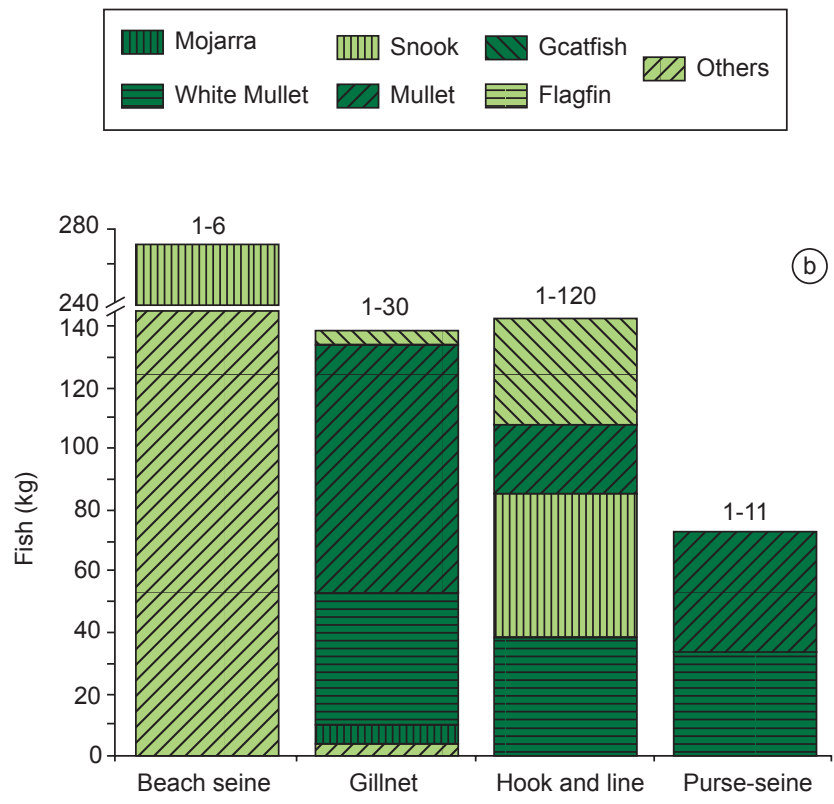

Fishing technology

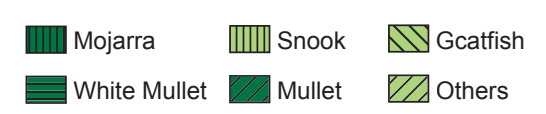

Figure 2. Catch composition for each technique. The numbers above the bars indicate the number of trips (n). a) 1992/93; and b) 2002/03.

Figura 2. Composição do pescado para cada técnica de pesca. Números acima das barras representam o número de viagens (n) a) 1992/93; e b) 2002/03.

\section{Discussion}

\section{Fish production and fish landing composition}

The techniques and targets of artisanal fishing in this community did not change during the time period considered. In 2002/03, fishing was still done by only a few community members who targeted the same species. Nevertheless, some fish of commercial importance and others that were only used as food in 1992/93 were absent from 
Table 1. Occurrence of each fish species (kg and number of trips) for both followed periods.

Tabela 1. Ocorrência de cada espécie de peixe ( $\mathrm{kg}$ e número de viagens) para ambos os períodos acompanhados.

\begin{tabular}{|c|c|c|c|c|c|c|c|c|c|}
\hline \multirow[t]{2}{*}{ Family and scientific name } & \multirow[t]{2}{*}{ English name } & \multicolumn{2}{|c|}{$\begin{array}{c}\text { Biomass } \\
1992 / 93\end{array}$} & \multicolumn{2}{|c|}{$\begin{array}{c}\text { Biomass } \\
2002 / 03\end{array}$} & \multicolumn{2}{|c|}{$\begin{array}{c}\text { Trips } \\
1992 / 93\end{array}$} & \multicolumn{2}{|c|}{$\begin{array}{c}\text { Trips } \\
2002 / 03\end{array}$} \\
\hline & & $\begin{array}{c}\text { Total } \\
\text { kg }\end{array}$ & $\%$ & $\begin{array}{c}\text { Total } \\
\text { kg }\end{array}$ & $\%$ & $\mathbf{N}$ & $\%$ & $\mathbf{N}$ & $\%$ \\
\hline \multicolumn{10}{|l|}{ ARIIDAE } \\
\hline Genidens genidens & Guri sea catfish & 605.8 & 74.2 & 39.5 & 6.3 & 13 & 12.0 & 9 & 5.4 \\
\hline \multicolumn{10}{|l|}{ ATHERINOPSIDAE } \\
\hline Odontesthes sp. & Pejerrey & 0.3 & 0.0 & - & - & 1 & 0.9 & - & - \\
\hline \multicolumn{10}{|l|}{ CARANGIDADE } \\
\hline Trachinotus spp. & Pompano & 1.3 & 0.2 & - & - & 2 & 1.9 & - & - \\
\hline Oligoplites spp. & Leatherjack & - & - & 1.0 & 0.2 & - & - & 1 & 0.6 \\
\hline Trachinotus carolinus & Florida pompano & 2.4 & 0.3 & - & - & 4 & 3.7 & - & - \\
\hline Decapterus spp., Caranx latus & Scad & 4.35 & 0.5 & 0.3 & 0.1 & 5 & 4.6 & 0 & 0.6 \\
\hline \multicolumn{10}{|l|}{ CENTROPOMIDAE } \\
\hline Centropomus undecimallis, C. parallelus & Snook & 79.35 & 9.7 & 134.9 & 21.7 & 50 & 46.3 & 30 & 18.0 \\
\hline CICLIDAE & Cichlid & 0.8 & 0.1 & 0.1 & 0.0 & 1 & 0.9 & 1 & 0.6 \\
\hline \multicolumn{10}{|l|}{ ELOPIDAE } \\
\hline Elops saurus & Ladyfish & - & - & 0.0 & 0.0 & - & - & 1 & 0.6 \\
\hline \multicolumn{10}{|l|}{ GERREIDAE } \\
\hline Diapterus olisthostomus & Mojarra & 11.8 & 1.4 & 7.4 & 1.2 & 14 & 13.0 & 12 & 7.2 \\
\hline Eucinostomus melanopterus & Flagfin & 6.5 & 0.8 & 0.6 & 0.1 & 5 & 4.6 & 5 & 3.0 \\
\hline HAEMULIDAE & Porkfish & 1.1 & 0.1 & - & - & 2 & 1.9 & - & - \\
\hline Anisotremus surinamensis & Black margate & 4.6 & 0.6 & - & - & 3 & 2.8 & - & - \\
\hline Pomadasys sp. & Grunt & 0.7 & 0.1 & 3.1 & 0.5 & 2 & 1.9 & 4 & 2.4 \\
\hline \multicolumn{10}{|l|}{ LUTJANIDAE } \\
\hline Lutjanus griseus & Grey snapper & 2.0 & 0.2 & 180.0 & 28.9 & 1 & 0.9 & 1 & 0.6 \\
\hline \multicolumn{10}{|l|}{ MUGILIDAE } \\
\hline Mugil curema & White mullet & 63.25 & 7.8 & 111.6 & 17.9 & 12 & 11.1 & 51 & 30.5 \\
\hline Mugil gaimardianus & White mullet & 0.4 & 0.0 & 0.4 & 0.0 & 1 & 0.9 & 1 & 0.6 \\
\hline \multicolumn{10}{|l|}{ POLYNEMIDAE } \\
\hline Polydactylus oligodon & Littlescale threadfin & 0.2 & 0.0 & 0.1 & 0.0 & 1 & 0.9 & 1 & 0.6 \\
\hline \multicolumn{10}{|l|}{ SCIAENIDAE } \\
\hline Larimus breviceps & Shorthead drum & - & - & 0.2 & 0.0 & - & - & 1 & 0.6 \\
\hline Menticirrhus littoralis & Kingcroaker & 1.6 & 0.2 & - & - & 2 & 1.9 & - & - \\
\hline Micropogonias furnieri, Umbrina coroides & $\begin{array}{l}\text { Whitemouth croacker/ } \\
\text { Sand drum }\end{array}$ & 3.0 & 0.4 & - & - & 1 & 0.9 & - & - \\
\hline \multicolumn{10}{|l|}{ SERRANIDAE } \\
\hline Epinephelus marginatus & Grouper & 1.9 & 0.2 & - & - & 2 & 1.9 & - & - \\
\hline Juveniles of many species & Small fishes & - & - & 1.8 & 0.3 & - & - & 4 & 2.4 \\
\hline Total & & 816.1 & - & 435.7 & - & 130 & - & 93 & - \\
\hline Zero & & - & - & - & - & 23 & - & 43 & - \\
\hline
\end{tabular}

Table 2. Catch, capture per unity of effort and diversity index (Shannon) for each month, in both periods.

Tabela 2. Captura, Captura por Unidade de Esforço e índice de diversidade (Shannon) para cada mês, em ambos os períodos.

\begin{tabular}{|c|c|c|c|c|c|c|c|c|c|c|c|c|}
\hline \multirow[t]{2}{*}{ Month } & \multicolumn{2}{|c|}{ Catch (kg) } & \multicolumn{2}{|c|}{ Number of fishers } & \multicolumn{2}{|c|}{$\begin{array}{c}\text { CPUE (kg fishers }{ }^{-1} \text { time } \\
\left.\text { fishing in minutes }{ }^{-1}\right)( \pm \mathrm{SD})\end{array}$} & \multicolumn{2}{|c|}{ Shannon $\left(\log _{n}\right)$} & \multicolumn{2}{|c|}{ Richness } & \multicolumn{2}{|c|}{ Evenness } \\
\hline & $92 / 93$ & $02 / 03$ & $92 / 93$ & $02 / 03$ & $92 / 93$ & $02 / 03$ & $92 / 93$ & $02 / 03$ & $92 / 93$ & $02 / 03$ & $92 / 93$ & $02 / 03$ \\
\hline October & 26.3 & 263.2 & 11 & 13 & $0.62(1.14)$ & $1.26(3.05)$ & 0.89 & 0.91 & 6 & 7 & 0.50 & 0.47 \\
\hline November & 34.4 & 29.2 & 10 & 17 & $0.45(0.64)$ & $0.29(0.51)$ & 1.21 & 0.75 & 9 & 9 & 0.55 & 0.34 \\
\hline January & 625.6 & 88.6 & 10 & 19 & $15.32(32.41)$ & $0.51(0.54)$ & 0.23 & 1.25 & 9 & 4 & 0.11 & 0.90 \\
\hline February & 26.5 & 59.8 & 9 & 10 & $0.60(0.66)$ & $0.82(1.81)$ & 1.66 & 0.89 & 11 & 7 & 0.69 & 0.46 \\
\hline May & 61.9 & 59.4 & 9 & 14 & $0.69(0.75)$ & $0.39(0.47)$ & 1.21 & 1.14 & 8 & 6 & 0.58 & 0.64 \\
\hline June & 41.5 & 127.6 & 9 & 12 & $0.54(0.53)$ & $1.23(2.05)$ & 1.39 & 0.71 & 8 & 7 & 0.67 & 0.37 \\
\hline
\end{tabular}


Table 3. Diversity index for both sampled periods (1992/93 and 2002/03), according to each technology.

Tabela 3. Índice de diversidade para ambos os períodos acompanhados (1992/93 e 2002/03), de acordo com cada tecnologia de pesca.

\begin{tabular}{lcccc}
\hline & \multicolumn{2}{c}{$\mathbf{1 9 9 2 / 9 3}$} & \multicolumn{2}{c}{$\mathbf{2 0 0 2 / 0 3}$} \\
\cline { 2 - 5 } & Shannon & Evenness & Shannon & Evenness \\
\hline Hook and line & 1.26 & 0.48 & 1.44 & 0.58 \\
Gillnet & 1.54 & 0.79 & 1.09 & 0.50 \\
Purse-seine & 0.69 & 0.29 & 0.83 & 0.60 \\
Beach seine & - & - & 0.67 & 0.48 \\
\hline
\end{tabular}

$t$ test: difference between the diversity index (Zar 1984), Hook and line ${ }_{92 / 93}$ $x$ Hook and line ${ }_{02 / 03}(t=5.24, \mathrm{p}<0.001, \mathrm{df}=182)$ Gillnet $_{92 / 93} x_{\text {Gillnet }_{02 / 03}}$

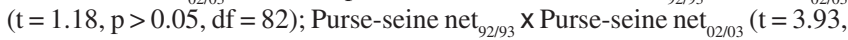
$\mathrm{p}<0.001, \mathrm{df}=98$ )

Teste $t$ : diferença entre índices de diversidade (Zar 1984), Anzol e linha ${ }_{92 / 93} \mathrm{X}$ Anzol e linha ${ }_{02 / 03}(t=5.24, \mathrm{p}<0.001, \mathrm{df}=182)$; Rede de espera ${ }_{92 / 93} \times$ Rede de espera $_{02 / 03}(t=1.18, \mathrm{p}>0.05, \mathrm{df}=82)$; Cerco de rede ${ }_{92 / 93} \times$ Cerco de rede $_{02 / 03}$ $(\mathrm{t}=3.93, \mathrm{p}<0.001, \mathrm{df}=98)$.

fish landings sampled at Puruba in 2002/03. Moreover, there was a reduction in the estimated daily and annual amount of fish caught and in the average amount (in $\mathrm{kg}$ ) caught on each trip, suggesting a decline in the fish populations of local interest. This decline probably reflected the fact that these species are the same as those targeted by industrial fishing, which is frequent in the Ubatuba region (Silva \& Carneiro 2000) and along the entire southeastern coast. Other possible reasons may include environmentally destructive actions, such as the removal of the riparian forest buffer and of river sand, which may account for changes in the predominant fish species caught (as also indicated by the low similarity index between the periods). Changes in the riparian zone can alter fish assemblages since, in addition to maintaining river bank stability, this zone also provides shade, cover and invertebrate food organisms, and maintains the water quality (Growns et al. 2003). Re-orientation in the fishing strategies could also have contributed to the changes in species composition. However, this seems improbable when one examines the changes in fishing technology used in this community. For example, fishermen used to base their commercial activities on purse-seine fishing and capture of the catfish $G$. genidens. If the hypothesis of re-orientation were true, we would expect a decrease in the use of purse-seine fishing or a change in the fishing spots used, but not in the diversity of species caught. However, the species diversity increased while the median return using purse-seine fishing fell (from $29 \mathrm{~kg}$ /trip to less than $7 \mathrm{~kg} /$ trip), despite fishing at the same spots. Another way of proving that the diversity of fish landings reflected the local environmental diversity, and not just changes in the fishing gear and target fish, would be to compare the diversity of species caught in experimental fishing and in fish landings (Silvano et al. 2000).

It is not reasonable apparently to assume that local fishing was the main cause of the decline in the catch, since fishing was never so intense compared to industrial fishing, despite the relatively significant catches of guri sea catfish in the first period through the purse seine method. However, it may have contributed to it and the current unrestricted use of gillnet may worsen the process, demanding some specific management measures. Although fish length was never measured in this study, it was noticeable the capture of small fish through the gillnet method in the second period, increasing the concerns about the sustainability of such method, even if this is just the consequence of a lack of bigger fishes due to industrial fishing.
These changes in fish composition and in the average catch were partially responsible for the abandonment of commercial artisanal fishing. Apparently, this community, and caiçara communities in general, are in the process of substituting artisanal fishing and other artisanal activities, such as cassava cultivation, for tourism (Diegues 2002). Other places in Brazil, such as communities located on the Araguaia River in the Amazon (Begossi 2001), have suffered a similar process, with partial or total abandonment of artisanal fishing and redirectioning of their activities to recreational fishing.

Although the average catch (in $\mathrm{kg}$ ) on each trip has fallen and the number of fishing trips with no yield has increased, the values found in 2002/03 were not very different from those observed in other caiçara communities on the northern coast of São Paulo state. In the nearby community of Ponta da Almada, Hanazaki \& Begossi (2000) observed an average fish catch of $5 \mathrm{~kg}$ on each trip and 33\% of the trips resulted in no yield. Begossi (1996) also reported similar values for Búzios Island (São Paulo), with an average catch of $4 \mathrm{~kg}$ of fish per trip and no yield in $24 \%$ of the sampled landings. These findings indicate either that fishing at Puruba, although low, is still satisfactory comparable to other places along the coast of São Paulo, or that fishing has been declining along the entire coast, a possibility that has not yet been examined in detail.

The current effort in the area by local people cannot be considered dangerous to the local resources, since only a few people still fish and what is caught is barely enough to feed the fishermen's family. However, the methods employed (specifically gillnet) should be subjected to a stricter control as juveniles of many species are eventually caught in these nets.

\section{Fishing technologies}

In Puruba, purse-seine fishing was the most specific method since it depends on the visual location of fish shoals. Contrary to other studies (Castro \& Begossi 1995), the use of hook and line provided the highest fish diversity in this environment, probably because many species in estuarine habitats have similar dietary habits (Figueiredo 1977) and also because the fishermen at Puruba do not fish with nets of different meshes on the same fishing trip; they usually use either small $(6 \mathrm{~cm})$ or large (especially 11 and $16 \mathrm{~cm})$ mesh nets. Intermediate mesh $(8$ and $10 \mathrm{~cm})$ nets were used only a few times $\left(\mathrm{n}_{1992 / 93}=1 ; \mathrm{n}_{2002 / 03}=2\right)$. On the Piracicaba river, in São Paulo state, Silvano \& Begossi (2001) observed that the highest species diversity was captured when the fishermen used intermediate mesh nets or a mixture of small and large meshes. In 1992/93, nets were more selective than in $2002 / 03$, perhaps because the smallest individuals or low value species were discarded, something that fishermen would be less able to do in 2002/03, when fish were scarcer. However, since we did not accompany the fishing trips, we cannot guarantee that there was no bycatch discard.

Although the diversity of fish caught using each technology was not different between the two periods for two of the compared technologies, some aspects are certainly distinct. Purse-seine fishing was the main method used when the fish caught were to be commercialized, especially guri sea catfish. Industrial fishing done with a net specially designed to catch catfish was, according to the Puruba fishermen, the main factor responsible for the difficulty in finding this species in 2002/03. This anecdotal information seems reasonable since the statistical registers for commercial and industrial catfish fishing in this region indicate high captures (> 25 t) in the 1990's, with a sharp decrease in 2001 and 2002 (Instituto de Pesca database, www.pesca.sp.gov.br). These industrial nets are placed along the entire beach by large fishing boats coming from other sites of Ubatuba or from other coastal cities and prevent the fish from approaching the beach. Consequently, artisanal fishing of this catfish is currently 
restricted to the use of hook and line, which does not depend on the presence of big shoals. Since the sale of fish was totally abandoned because of the difficulty in capturing commercially valued species, the use of purse-seine has declined and is more important only during the winter, possibly because of the arrival of migratory species such as mugilids. There has been a substitution of purse-seine fishing by gillnet fishing, perhaps because the latter method requires little effort, an important aspect for fishermen who now have other jobs.

Hook and line fishing has assumed a recreational nature. While in the past the main targets were commercial fish, such as snook and catfish, this form of fishing is now considered a leisure activity, although some of the targeted fish are still commercially valuable. Nonetheless, the method of capturing high valued species has changed, especially the capture of mugilids. In the past, when these species were destined for commerce, they were fished with gillnets and purse-seine nets since they are detritivorous species (Figueiredo 1977) that are difficult to capture with hook and line. In 2002/03, mullet and white mullet were being fished with hook and line using pieces of bread or a bread paste as bait, as done by recreational fishermen.

Although there was no significant difference between the CPUEs of the two periods, there was a tendency towards a decrease in fish biomass and diversity in 2002/03, associated with an increase in the diversity of species caught with each technology. By increasing diversity, these fishermen may be using a strategy of diversification, as described by McCay (1978), in which they try to expand their production (becoming less selective during fishing and looking for new sources of income) in order to cope with environmental problems. Fishermen on the Piracicaba River have also adopted a strategy of diversification in which they become less selective in their fishing during the high water season, when the availability of the desired fish species drops (Silvano \& Begossi 2001). Nevertheless, the strategy observed at Puruba may represent an interim solution since there is a tendency towards the total abandonment of fishing, replacing it by more secure and profitable alternatives. The difficulty in catching guri sea catfish has led to the demise of local fishing for commerce.

Fishermen at Allepey, southeastern India, faced a similar situation in the past, when there were intense incentives for commercial fishing leading to overfishing of a large variety of species (Chacko 1998). In Mozambique, de Boer et al. (2001) also observed that intense artisanal fishing in the region led to alterations in the composition of fish landings and in the average amount of fish per catch. Nevertheless, the cause of the changes in Mozambique (intense artisanal fishing) seems different from that at Puruba (possibly intense commercial fishing).

\section{Alternatives for management}

The Puruba Beach community, like other caiçara communities, is undergoing a transition in which the extraction of natural resources based on local traditions is being substituted for aspects that depend totally on external resources, mainly tourism. This apparently happens due to the difficulties in making a living off of their local resources. Tourism in caiçara communities, in addition to introducing new habits in fishing, food consumption and customs, uses local people as cheap laborers, for building summer houses and employing local women as maids, albeit it also offers an opportunity to earn some money on holidays through running small restaurants and house renting. Although some of these issues suggest that tourism has a positive side, the way it was being done in 2002/03 meant that only a few people could benefit from it and most of them were not even local people, such as most of the owners of rental houses.

Obviously, communities can respond differently to external pressures. For example, tourism has impacted communities on the banks of the Araguaia river (Brazil) and has led to the partial or total abandonment of fishing (Begossi 2001). At Camburi Beach, another caiçara community in São Paulo state, tourism has led to an intense exodus and the sale of property, limiting the job options and contributing to increasing thefts, prostitution and the abuse of drugs among youths (Hanazaki \& Begossi 2000). The outcome of unplanned tourism is seen in many places besides Brazil. In South Carolina (USA), the advance of tourism led small proprietors to sell their land and become cheap laborers, also leading to economic, social and cultural transformations (Faulkenberry et al. 2000). In Korea, government efforts to favor tourism in fishing communities showed that fishermen had a hard time participating in the business because of the high cost of investment that resulted in more opportunities for outsiders than for local people (Cheong 2003).

Management of the community resources solely by the caiçaras is currently unfeasible given the presence of tourists, with some of them already dwelling in the community. Any proposed management alternative should consider these new residents and seek to empower the local community through an active participation of all community members (Ruddle 1993). Indeed, it is important that the control of resources be done by the community, supported by public institutions, universities and non-governmental organizations, in contrast to unilateral policies imposed by the government (Acheson \& Wilson 1996, Reis \& D'Incao 2000, Schreiber 2001) or where large-scale fishing concerns override local decisions (Wiber et al. 2004). Even smaller countries than Brazil may have a huge range in biodiversity and socio-cultural diversity, which influences their regional and local economies, demanding decentralized and community-based approaches (Siry 2006), with an intense participation of the local people. Measures developed for one region may not apply to another. Moreover, sometimes local people rely on traditional practices that can be sustainable in the long run - some of them have been in use for a long time - (Siry 2006), just requiring some minor changes or studies confirming their effectiveness to manage their local resources.

Co-management is a relatively novel concept, hence truly successful cases are still hard to find. It brings up important issues concerning ownership, as areas usually under an open access system start to be managed and controlled by local people supported by the government, converting them in regions governed by the commons (Siry 2006). Some countries, such as the Philippines (Pomeroy \& Carlos 1997) and South Africa (Hauck \& Sowman 2001), have accumulated considerable experience in this area and provide an opportunity to learn from them. Based on the experience of these countries and on caiçaras characteristics, we propose some general management alternatives that can be applied not only in Puruba, but in many other communities along the Brazilian coast and elsewhere, where similar conditions occur (Figure 3). Based on the constant low fishing effort in Puruba, it is supposed here that part of the local decline of the CPUE and fish species was due to industrial fishing. Due to that and to other social, cultural and economic factors, these measures do not aim at restoring the pristine fishing conditions, but only at improving and valuing their lives in their original place in a way that they can keep making a living off of their local resources, however in a different way and maybe not having fish as their main resource:

1) Management of local fisheries. Despite not intending to restore pristine conditions, local fishing methods and management practices can and might be improved, as fish works as a source of healthy and cheap animal protein for local people, besides working nowadays secondarily as a source of income:

- enforcement of minimum allowed sizes for catching snook and mullet, their main fish targets. Even though such species have a minimum size already established by law (mullet $=$ $35 \mathrm{~cm}$, snook $=35$ C. paralellus and $50 \mathrm{~cm} \mathrm{C.} \mathrm{undecimalis),}$ it is necessary to make the community conscious about the 


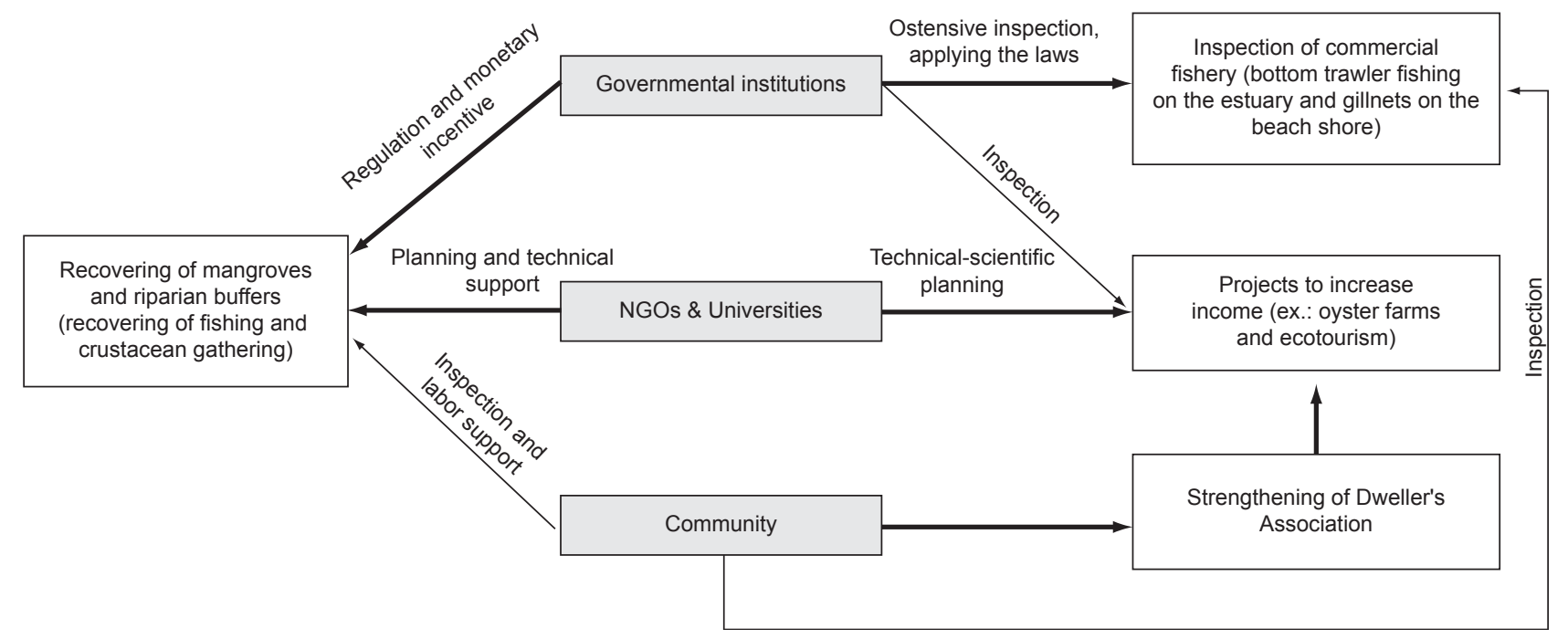

Figure 3. Suggestion for a co-management strategy involving public institutions, universities, NGOs and the community. The width of each arrow indicates the suggested degree of participation of each entity.

Figura 3. Sugestões para uma estratégia de co-manejo envolvendo instituições públicas, universidades, ONGs e a comunidade. A espessura de cada seta indica o grau de participação de cada entidade.

relevance of enforcing these rules to themselves and to other sport fishermen who visit the area.

- establishment of minimum mesh sizes for purse seine and gill nets. In order to avoid the capture of juveniles, fishermen should use proper mesh sizes, but the ideal mesh size should be based on local studies of fish development, as such conditions can vary from place to place. Fortunately, the Brazilian Environmental Protection Agency (IBAMA) has adopted different management initiatives in different areas lately (ex.: normative instruction 85, Jan. 05, 2006 - www.ibama.gov.br/pndpa/ legislacao.php?id_arq=117). Due to fishermen's requests, we have been conducting studies on snook reproduction in the area as a way of providing such information.

- control of sport fishing on the beach and local rivers. The community, in its current situation, cannot forbid the access of sport fishermen or establish an official licensing system, but they can give instructions and help enforce the current laws (minimum allowed size, use of appropriate gear, etc.). In the future, if a co-management regime takes place, sport fishing should be taken seriously through a licensing system that controls who and the number of people that can use the area each day, besides establishing limits to the amount of fish that can be caught by each person. Such system can also generate some income to the village if the sport fishermen pay a short fee (daily or annual) to use the area.

2) The development of alternative economic projects that bring profits to the entire community and stimulate its members to continue living locally.

- participative ecotourism through the education of the local youth, who can work as monitors. Alternatives such as trails and jaunts along rivers and recreational fishing can be explored.

- evaluation of the possibilities of establishing of oyster or mussel farms in the estuary.

3) Environmental restoration of the location:

- the recovery of mangroves and riparian zone, which can result in improved fishing and crustacean gathering, in addition to enhancing the possibilities of ecotourism. Estuaries in general, and mangroves in particular, are fundamental nursery areas for invertebrate and fish communities (Levinton 1995).

4) Assurance of the right of local inhabitants to use marine resources:

- access rights must respect the fishing spots used by the community and prohibit the approach of commercial boats that intend to use beach seine nets or to fish at the mouth of rivers, an outlawed activity that is commonly practice in the region by outside fishermen. The access rights might include respect for a minimal distance from the coast for the use of gillnets and the establishment of a period for the use of these nets, according to the target species.

- Establishment of protected areas:

- establishing places for the total protection of fishing resources that can act as reproductive and nursery grounds (Roberts et al. 2001, Pauly et al. 2002). The establishment of marine protected areas also allows underwater photography, ecotourism and scientific studies (Lam 1998).

Many of these suggestions will only be successful if they encompass an area larger than that pertaining to only one community, thus making the involvement of other communities necessary. This would make possible, for example, the establishment of no-take reserves, as some beaches will have different habitats (rock, sand or mud bottom) attracting different species. This also increases the potential of having more nursery sites. However, to establish co-management initiatives for fishing, the government should be willing to decentralize its authority by delegating greater responsibilities and power to the local fishermen (Pomeroy \& Carlos 1997). Until de mid 1980's most fishery management initiative would rely exclusively on biological characteristics of fish (e.g., maximum sustainable yield), whereas economic aspects were just included later on. Only recently, it has been paid attention to the social and cultural aspects of fishermen and their communities as well, as they noted that management was just viable when taking these factors into account (Thompson et al. 2003). They now consider, for example, age structure, other sources 
of income, education level and community size before proposing restrictions and limitations, as it is known that people will not comply if they cannot make a living off of other sources. Measures to curtail effort (restricted number of days to fish, individual quotas, seasonal catch limits) are more successful if it is done in an adaptive way (changing according to the conditions) and never losing track of local social and economic transitions (Lee 1999). The success in applying management initiatives also depends on economic factors, such as the transaction costs, defined as the costs associated with the coordination of people and information in an environment of uncertainty. Hanna (2003) highlighted the importance of transaction costs for the success of these initiatives and demonstrated the relevance of initial problems, such as the transfer of skills to fishermen, the absence of a democratic tradition, the control of poorly defined boundaries, poor policy coordination among the different administrative levels, uncertainty about funds, difficulty in biological monitoring and the existence of conflicts among different groups of fishermen. Many or all of these problems may occur in Puruba and in Brazil as a whole.

The few initiatives that have worked properly in Brazil, such as the reserves and protected areas in the Amazon (Begossi \& Brown 2003, McGrath et al.1993), have a long history of collective action and democratic participation. However, in the Atlantic forest, there is no such local organization and almost all forms of management initiatives, such as fishing territories (Begossi 2001), are still incipient. The lack of organization along the Brazilian coast increases the transaction costs and may make the immediate adoption of co-management initiatives difficult in this area. For example, the government tried to create a maritime extractive reserve at Itaipu Beach (Rio de Janeiro state) and found strong resistance from the users because they did not feel that they were part of this arrangement (Begossi 2006). In Arraial do Cabo, another city in Rio de Janeiro state, a maritime extractive reserve was created with little government support and was abandoned to formal and informal institutions in the local community (Silva 2004). In other countries, such as Bangladesh (Thompson et al. 2003), Indonesia (Bailey \& Zerner 1992) and South Africa (Hauck \& Sowman 2001), initial difficulties similar to those encountered in Brazil were also faced, with one of the most important and pervasive being the lack of coordination and preparation by the government to support such initiatives. Before the adoption of a co-management system in any community, the transition costs may be reduced by establishing local institutions (e.g. a dwellers' organization) and by transferring skills and delegating power from the government to communities, while maintaining the participation of these different levels.

\section{Conclusions}

Despite the relatively short time period considered here, some relevant changes were observed in the fishing activities at Puruba that culminated in the demise of commercial artisanal fishing. At first glance, such changes are difficult to notice since the local fishermen still use the same methods and continue to practice non-intensive fishing. However, they have re-oriented the use of some methods, such as the reduced use of purse-seine nets and increased use of gillnets. The changes probably resulted from the lower total catch nowadays and the different composition of fish species present in the fish landings, the latter attributable to uncontrolled industrial fishing along this shore, as well as other factors. We believe that the results described here are representative of the Brazilian coast in general since caiçara communities show similar features and face similar external pressures, such as industrial fishing and tourism, throughout this entire region. However, there is still a need for additional studies to compare temporal changes in fishing in other communities in order to have a more precise understanding of the changes along the Brazilian coast.

We have suggested co-management alternatives that can be useful to caiçara communities, but that can also be adopted by coastal communities elsewhere. These alternatives provide a means of softening the impacts of such changes in small-scale fishing communities and also of facilitating resource conservation. We hope that these suggestions may be considered as a first step towards the organization of caiçara fishermen and that they may be useful in other rural coastal groups (e.g. in Moçambique, Tanzania, India and Bangladesh). Once the political and organizational obstacles have been overcome, the sustainable use of the environment by such communities, mainly through fishing and tourism, is not impossible but will depend on the cooperation of the fishermen, governmental institutions and NGO's.

\section{Acknowledgments}

P.F.L.MC. was supported by an MSc studentship from CAPES and A.B. was supported by a research fellowship from CNPq. This work was supported by FAPESP (grant no. 01/05263-2). We thank J. L. Figueiredo for identifying the fish. Renato A. M. Silvano provided many valuable suggestions and comments. We are indebted to the caiçara families for making this research possible and for their hospitality. In particular, we thank Donizete for his help during the data collection in 1992/93.

\section{References}

ACHESON, J.M. \& WILSON, J.A. 1996. Order out of chaos: the case for parametric fisheries management. Am. Anthropol. 98(3): 579-594.

ASWANI, S. 1998. Patterns of marine harvest effort in southwestern New Georgia, Solomon Islands: resource management or optimal foraging? Ocean. Coast. Manage. 40(2-3): 207-235.

BAILEY, C. \& ZERNER, C. 1992. Community-based fisheries management institutions in Indonesia. MAST 5(1): 1-17.

BEGOSSI, A. 1995. Fishing spots and sea tenure in Atlantic Forest coastal communities: incipient forms of local management. Hum. Ecol. 23(3): 387-406.

BEGOSSI, A. 1996. Fishing activities and strategies at Búzios Island, Brazil. In Proceedings of the World Fisheries Congress, Theme 2 (C. Zhang, M. L. Windsor \& B. J. McCay, eds). Science Publishers, New Hampshire, p. $124-140$.

BEGOSSI, A. 2001. Cooperative and territorial resources: Brazilian artisanal fisheries. In The commons revisited: an American perspective (J. Burger, R. Norgaard, E. Ostrom, D. Policansky \& B. Goldstein, eds). Island Press, Washington, p.109-130.

BEGOSSI, A. 2004. Áreas, pontos de pesca, pesqueiros e territórios na área artesanal. In Ecologia de pescadores da Mata Atlântica e da Amazônia (A. Begossi, org.). Editora Hucitec, São Paulo, Brazil, p. 223-253.

BEGOSSI, A. 2006. Temporal stability in fishing spots: conservation and co-management in Brazilian artisanal coastal fisheries. Ecol. Soc. 11(1): http://www.ecologyandsociety.org/vol11/iss1/art5/ (ultimo acesso em 17/06/2008).

BEGOSSI, A. \& BROWN, D. 2003. Fisheries co-management experiences in Latin America and the Caribbean. In The fisheries co-management experience: accomplishments, challenges and prospects, Fish Fish. Series 26 (D. C. Wilson, J. R. Nielsen \& P. Degnbol, eds). Kluwer Academic Publishers, Dordrecht, The Netherlands, p.135-150.

BERKES, F. 1985. Fishermen and 'The Tragedy of the Commons'. Environ. Conserv. 12(3): 199-206.

DE-BOER, W.F., VAN-SCHIE, A.M.P., JOCENE, D.F., MABOTE, A.B.P. \& GUISSAMULO. A. 2001. The impact of artisanal fishery on a tropical intertidal benthic fish community. Environ. Biol. Fish. 61(2): 213-229. 
CASTRO, F. \& BEGOSSI, A. 1995. Ecology of fishing at Rio Grande, Brazil: technology and territorial rights. Fish. Res. 23(3): 361-373.

CETRA, M. \& PETRERE, JR.M. 2001. Small-scale fisheries in the middle River Tocantins, Imperatriz, MA, Brazil. Fisheries Manag. Ecol. 8(2): 153-162.

CHACKO, T. 1998. Artisanal fishing along the Allepey coast, southwest India. Hum. Organ. 57(1): 60-62.

CHEONG, S.M. 2003. Privatizing tendencies: fishing communities and tourism in Korea. Mar. Policy 27(1): 23-29.

COSTA, P.A.S., BRAGA, A.C. \& ROCHA, L.O.F. 2003. Reef fisheries in Porto Seguro, eastern Brazilian coast. Fish. Res. 60(2): 577-583.

DIEGUES, A.C.S. 1999. Human population and coastal wetlands: conservation and management in Brazil. Ocean. Coast. Manage. 42(2): 187-210.

DIEGUES, A.C.S. 2002. Povos e Águas: inventário de áreas úmidas brasileiras. 2nd ed. NUPAUB, São Paulo, Brazil.

FAULKENBERRY, L.V., COGGESHALL, J.M., BACKMAN, K. \& BACKMAN, S. 2000. A culture of servitude: the impact of tourism and development on South Carolina's coast. Hum. Organ. 59(1): 86-95.

FEENY, D., BERKES, F., MCCAY, B. J. \& ACHESON, J.M. 1990. The tragedy of the commons: twenty-two years later. Hum. Ecol. 18(1): $1-19$.

FIGUEIREDO, J.L. 1977. Manual de peixes marinhos do Sudeste do Brasil. V. Teleostei. Museu de Zoologia da Universidade de São Paulo, São Paulo, Brazil.

FRIEDLANDER, A.M. \& PARRISH, J.D. 1997. Fisheries harvest and standing stock in a Hawaiian Bay. Fish. Res. 32(1): 33-50.

GROWNS, I., GEHRKE, P.C., ASTLES, K.L. \& POLLARD, D.A. 2003. A comparison of fish assemblages associated with different riparian vegetation types in the Hawkesbury-Nepean River system. Fisheries Manag. Ecol. 10(4): 209-220.

GUEST, G. 2003. Fishing behavior and decision-making in an Ecuadorian community: a scaled approach. Hum. Ecol. 31(4): 611-644.

HANAZAKI, N. \& BEGOSSI, A. 2000. Fishing and niche dimension for food consumption of Caiçaras from Ponta do Almada. Brazil. Hum. Ecol. Rev. 7(2): 52-62.

HANNA, S. 2003. The economics of co-management. In Fisheries comanagement experiences in Latin America and the Caribbean, Fish and Fisheries, Series 26 (D.C. Wilson, J.R. Nielsen \& P. Degnbol, eds). Kluwer Academic Publishers, Dordrecht, The Netherlands, p. 51-60.

HAUCK, M. \& SOWMAN, M. 2001. Coastal and fisheries co-management in South Africa: an overview and analysis. Mar. Policy 25(3): 173-185.

HILBORN, R. 1985. Fleet dynamics and individual variation: why some people catch more fish than others. Can. J. Fish. Aquat. Sci. 42(1): $2-13$

JENTOFT, S. \& MCCAY, B. 1995. User participation in fisheries management: lessons drawn from international experiences. Mar. Policy 19(3): 227-246.

JIDDAWI, N.S. \& ÖHMAN, M.C. 2002. Marine fisheries in Tanzania. Ambio 31(7-8): 518-527.

LAM, M. 1998. Consideration of customary marine tenure system in the establishment of marine protected areas in the South Pacific. Ocean. Coast. Manage. 39(1-2): 97-104.

LEE, K.N. 1999. Appraising adaptive management. Conserv. Ecol. 3(2): http://www.ecologyandsociety.org/vol3/iss2/art3/ (último acesso em 25/06/2008).

LEVIEIL, D.P. \& ORLOVE, B. 1990. Local control of aquatic resources: community and ecology in Lake Titicaca, Peru. Am. Anthropol. 92(2): 362-382.

LEVINTON, J.S. 1995. Marine biology: function, biodiversity, ecology. Oxford University Press, New York, USA.

MACCORD, P.F.L., SILVANO, R.A.M., RAMIRES, M.S., CLAUZET, M. \& BEGOSSI, A. 2007. Dynamics of artisanal fisheries in two Brazilian
Amazonian reserves: implications to co-management. Hydrobiologia 583(1): 365-376.

MAGURRAN, A.E. 1988. Ecological diversity and its measurement. Princeton University Press, Princeton, USA.

MCCAY, B.J. 1978. Systems ecology, people ecology, and the anthropology of fishing communities. Hum. Ecol. 6(4): 397-422.

MCDANIEL, J. 1997. Communal fisheries management in the Peruvian Amazon. Hum. Organ. 56(2): 147-152.

MCGRATH, D.G., CASTRO, F., FUTEMMA, C., AMARAL, B.D. \& CALABRIA, J. 1993. Fisheries and the evolution of resource management on the Lower Amazon floodplain. Hum. Ecol. 21(2): 167-195.

MYERS, M., MITTERMEIER, R.A., MITTERMEIER, C.G., FONSECA, G.A.B. \& KENT, J. 2000. Biodiversity hotspots for conservation priorities. Nature 403(24): 853-858.

OKADA, E.K., AGOSTINHO, A.A. \& GOMES, L.C. 2005. Spatial and temporal gradients in artisanal fisheries of a large Neotropical reservoir, the Itaipu reservoir, Brazil. Can. J. Fish. Aquat. Sci. 62(3): 714-724.

PAUly, D., CHRISTENSEN, V., GUÉnETTE, S., PITCHER, T.J., SUMAILA, U.R., WALTERS, C.J., WATSON, R. \& ZELLER, D. 2002. Towards sustainability in world fisheries. Nature 418: 689-695.

POMEROY, R.S. \& CARLOS, M.B. 1997. Community-based coastal resource management in the Philippines: a review and evaluation of programs and projects, 1984-1994. Mar. Policy 21(5): 445-464.

REIS, E.G. \& D'INCAO, F. 2000. The present status of artisanal fisheries of extreme Southern Brazil: an effort towards community-based management. Ocean. Coast. Manage. 43(7): 585-595.

ROBERTS, C.M., BOHNSACK, J.A., GELL, F., HAWKINS, J. P. \& GOODRIDGE, R. 2001. Effects of marine reserves on adjacent fisheries. Science 294(5548): 1920-1923.

RUDDLE, K. 1993. External forces and changes in traditional communitybased fishery management systems in the Asia-Pacific region. MAST 6(1-2): 1-37.

RUTTENBERG, B.I. 2001. Effects of artisanal fishing on marine communities in the Galápagos Island. Conserv. Biol. 15(6): 1691-1699.

SCHREIBER, D.K. 2001. Co-management without involvement: the plight of fishing communities. Fish Fish. 2(4): 376-384.

SEIXAS, C.S. \& BEGOSSI, A. 2000. Central place optimal foraging theory: population and individual analysis of fishing strategies at Aventureiro, Ilha Grande, Brazil. Ciência e Cultura 52(2): 85-92.

SILVA, A.O.A. \& CARNEIRO, M.H. 2000. Produção pesqueira marinha do Estado de São Paulo no ano 2000. Série Relatórios Técnicos São Paulo. Instituto de Pesca, Brazil.

SILVA, P.P. 2004. From common property to common management: lessons from Brazil's first maritime extractive reserve. Mar. Policy 28(5): 419-428.

SILVANO, R.A.M., AMARAL, B.D. \&. OYAKAWA, O.T. 2000. Spatial and temporal patterns of diversity and distribution of the Upper Juruá River fish community (Brazilian Amazon). Environ. Biol. Fish. 57(1): 25-35.

SILVANO, R.A.M. \& BEGOSSI, A. 2001. Seasonal dynamics of fishery at the Piracicaba River, Brazil. Fish. Res. 51(1): 69-86.

SIRY, H.Y. 2006. Decentralized coastal zone management in Malaysia and Indonesia: a comparative perspective. Coast. Manage. 34(3): 267-285.

THOMPSON, P.M., SULTANA, P. \& ISLAM, N. 2003. Lessons from community based management of floodplain fisheries in Bangladesh. J. Environ. Manage. 69(3): 307-321.

WIBER, M., BERKES, F., CHARLES, A. \& KEARNEY, J. 2004. Participatory research supporting community-based fishery management. Mar. Policy 28(6): 459-468.

Data Received 21/09/07

Revised 10/01/08

Accepted 01/04/08 